\title{
Luther and Toleration
}

\section{By}

\author{
John Alfred Faulkner
}





\section{LUTHER AND TOLERATION}

\section{By John Alfred Faulkner, Drew Theological Seminary, Madison, New Jersey}

WHAT were Luther's views on religious toleration?
These are set forth for the first time in his little book, Von weltlicher Obrigkeit, wie weit man ihr Gehorsam schuldig sei (I523). I I give here a brief abstract of this epoch-making treatise.

The state exists by divine right. Its object is to keep peace, ward off evil deeds, punish the bad, and protect the good. Therefore Christians should subject themselves to the sword, and Christian rulers should bear the sword. The testimonies of Christ against the use of force, against oaths, etc., are intended only to forbid a selfish use, against private revenge, but not against the state as the guardian of peace and order. But this authority must not go beyond its own functionto keep external order. It cannot make men pious. God only rules the soul. No one should compel another to faith, which is a free work, a divine work in the spirit. Therefore we have the proverb, Thoughts are not taxable. In matters of the soul we must obey God rather than man. If tyrants take away our Bibles, suffer it, but do not give them up. As to rulers generally they are often a sorry set. From the beginning of the world till now a good clever prince is a rare bird; they are generally the greatest fools or the greatest scoundrels on earth. When you find a prince who is clever,

'Dr. Martin Luthers sämmtliche Werke, Erlangen 1826-1857, Bd.22, 59105. Extracts in Kōstlin, Martin Luther: sein Leben und seine Schriften, 5th Aufl., I., 582-4 (1903). (References are to the first Erlangen edition unless otherwise noted.) 
pious, and a Christian, that is the greatest wonder and the truest sign of the divine grace. But the world is too evil for good rulers, - it is not worthy of them. Frogs must have storks. But for all that, they are to be had in respect for their office, which is to punish evildoers and keep external peace. In regard to using

worldly power to ward off heresies,- - that is the work of bishops, not of princes. For heresy can never be prevented by force; God's word is to be used here; if that cannot do it, it will remain undone by secular power, even if the latter fills the world with blood. Heresy is a spiritual thing; it cannot be cut with iron, nor burnt with fire, nor extinguished with water.

The weapons against heresy are those mentioned in Isaiah xi:4. When God's word enlightens the heart, heresy falls of itself. To go at it with fire and sword is like fighting a lightning storm with a blade of straw. In a Christian spirit a prince should serve his subjects in love, and use punishment with intelligence and moderation. War is permissible if it is waged not for conquest but for protection of the people. Before it begins peace and right should be offered the enemy. As to matters of legislation, administration, etc., this is not his (Luther's) territory. Christ did not lay down distinct rules here, nor do I. Let reason decide those matters. Should I teach a tailor to make a coat? He knows already.

It will be seen from this how unfounded was the reproach of revolution brought against Luther, who later said: "I might boast that since the apostles' time the worldly and secular authority have never been so clearly described and highly praised, as even my enemies must confess, as by me." In fact, over against the Catholic conception Luther brought out fully the complete independent justification of the worldly power, and over against some of the Anabaptists Luther defended the right of the Christians to bear rule and wield the sword. He likewise rose superior to the views of 
some less-balanced spirits of the time that the state should be organized after a Scriptural pattern, especially after the Old Testament pattern. On the other hand Luther said: Let reason and circumstances govern in matters of organization, administration, and government. Hartwig is right when he says that it is Luther's undeniable service that he indicated the independent position of the state in opposition to the hierarchical assumptions of the Church on that territory. ${ }^{x}$

Luther wants the authorities to leave the Gospel a free field. He says the Gospel is God's affair, and he will see to it. "No sword can help it. God must alone care for it, without man's anxiety. Therefore who believes most will here protect most. Nor must the Elector step in too much. I want your Electoral Grace to know that I have received this Gospel not from man, but only from heaven through Jesus Christ." And should the emperor turn against him-for Luther was under the imperial ban-then let the elector be obedient to the imperial order and not go against the power which wants to imprison and kill him. For no one should oppose the power-that would be rebellion against God."

It is not to be wondered at that the opponents of Luther have charged him with slavish deference to power. Scherr says that Luther's politics was that of slave-blessedness (Knechtsseligkeit). He had nothing else and desired nothing else (according to Scherr) than a literal Biblical theology, and because he held this with the iron energy and perseverance of a narrow but unbending conviction he was able under favorable circumstances to impress upon a whole era of German history the stamp of the Protestant theological spirit, while so many of his contemporaries, with their deeper and larger endeavors for material and social freedom, saw their hopes shattered. ${ }^{3}$ But even here there was another

${ }^{1}$ Luthers Stellung zur Politik»Leipzig, 1899, 8.

53: 104-8 (1522).

3 Deutsche Kultur-und Sittengeschichte (6. Aufl.), 264. 
side to Luther. In a letter to the Elector, March 12, 1522, he justifies his leaving the Wartburg for Wittenberg without the Elector's knowledge or consent. He says that we should not always be obedient to authority, at least when the latter does anything against God. One should not despise it even then, for Christ showed respect to Pilate. I do not go to Wittenberg out of any lack of reverence for the emperor or yourself. Your Electoral Grace is lord of goods and bodies, but Christ is lord of the soul, which he has sent and awakened. On grounds of conscience, of love, and of fidelity I have come to Wittenberg, such grounds must hold against the favor or unfavor of the whole world. For not only worldly but also spiritual power must bend before the Gospel, if it proceeds with love and patience. For God will not judge me by another's faith but by my own conscience; for I know that my word and beginning are not from me but from God, so that neither persecution nor death can teach me otherwise. Wittenberg is my flock, my children in Christ. I am obligated to suffer even death for them. ${ }^{\mathrm{x}}$

He who said these words taught no slavish obedience, but rather "claimed the right of freedom of conscience for himself and all Christians but still only freedom of conscience, which feels itself bound to the highest norm of the divine right and law." 2 There was no cowardly slave-feeling there but a joyful courage of faith. It seems to me that Freytag is nearer the truth than Scherr when he says that in "such loyalty there was no slavish sense, and in his frequent intercourse with the great there was a bold openness which more than once shocked the court-folks. To his electoral prince he spoke truths in all duty as only a great character could speak." 3

The religious point of view ruled here. If the emperor wishes to force the subjects of the German princes from the

I $53: 114-8$.

2 Hartwig, 14.

3 Bilder aus der deutschen Vergangenheit: aus dem Jahrhundert der Reform., 102. 
Gospel, expel or kill them, and the princes know that in that the emperor does wrong against God, then they shall not obey him; otherwise they become partakers in his evil deeds. For we must obey God rather than man. ${ }^{x}$ But he is always exhorting to peace and moderation in all political relations. "Nothing is dearer to me than peace. I have hitherto taught peace as much as I could with diligence and with every man." 2

Awhile ago I quoted Luther against forcing the conscience on religious matters. He says again that if the authorities overstep their bounds in matters of conscience then one should say to them: "Well now, dear prince, dear worldly authority, I am under obligation to thee, but not against the Over-Lord, against God. I will be obedient to thee in the circle over which thy power stretches and thou shouldst not grip in on God's power." 3 "Over the soul God wants no other to reign than himself. No one can command the soul or show it the way to heaven but God alone. Therefore in matters of the soul God's word shall teach and be taken. ... It is impossible that among Christians the worldly sword and law should be invoked" (that is, in purely Christian matters)." "It belongs to every Christian (not to the pope or to the prince or clergy) to believe, to understand his faith, to contend for it and to condemn all errors." In saying that he gave a priceless banner to God's elect.

I came out against the pope, indulgences and all papists [he says in his second sermon at Wittenberg on his return from the Wartburg] but not with force, not with violence nor storm, but I have preached and written, and have had to do with God's word alone. If I had proceeded with force and trouble, I should have started such a plague that Germany would have soaked in blood. But what good would that do? A fool-play it would have been, and destruction to soul and body. I have sat still and let the Word act. 5

$$
\begin{aligned}
& \text { 54: I4I (I530); 25:50 (I53I). } \\
& \text { 422:82, } 83 \text { (I523). } \\
& 33: 333 \text { (1525). } 345: 115 \text {. } \\
& \text { s 28:219, } 220 \text { (1523). }
\end{aligned}
$$


In his introductory words in his great book, To the Christian Nobility of the German Nation (I520), he also warns against trusting to worldly power. We fight here not with men, but with princes, who though they may fill the world with blood are not thus overcome. "One must, forsaking bodily force, in humble trust in God take hold of the cause, and with earnest prayer seek help from God, and keep nothing before one's eyes but the miserable state of Christendom, without having regard to what bad people deserve." I

Luther says other fine things. Judicial proceedings (he says) can have nothing to do with matters of faith. For here is life, secret life in God, which only he who knows the heart can judge, a life full of constant development, full of the highest intensity, thoughts and feelings that flow here and there; to take up a matter of fact, as the court demands, is impossible, because faith ceases where the definition of a fixed quantity begins. "The wind bloweth where it listeth," etc. (quoting John iii: 8).

A court must be certain when it judges, and everything must be out in the clear light. But the soul, thoughts, feelings, can be revealed to no one except God; therefore it is impossible to command or force anyone to what he shall or shall not believe. It is an entirely different conception, where force has nothing to do. Every man has his own danger how he believes, ancihe must see to it for himself that he believes aright. For as little as one can go for me to heaven or hell, so little can he believe or not believe for me; and as little can he exclude me from heaven or include in hell, so little can he drive me to faith or unfaith. For faith is free. What could a heresy trial do anyway? It could do no more than to make the people follow in hand or mouth. It could not compel the heart. For true is the proverb: Tboughts are duty-free (zollfrei-not taxable). The soul is not under the emperor's power. $^{2}$

Therefore in the first edition of the instruction of the visitors to the pastors in the Electorate of Saxony, 1528, Luther 
says that "no one can be compelled to faith, nor be brought from unbelief by command or force, for no compelled service pleases God, who will have only voluntary service." 1 So also in one of his church-postils we find this great word: "It does not help-neither burnings nor bulls nor bans. If one should take every sword in his hand, that brings no heretic to faith. . . . Therefore God has done away with the sword (that is; all force) in this matter." I In his letter to the Elector Frederick and Duke John of Saxony (August 21, 1524), he uses the famous words to the effect that spirits must be let to play against each other, and not be forcefully repressed. We must fight with words, not with fists. To preach and suffer is our office. The apostles did not go to work with force, but to win hearts with God's word. Stone and wood are not for us but the hearts of men. Cloisters are empty through my word alone. If I had gone to work with storm, as these prophets, many would still be in captivity. ${ }^{3} \mathrm{Be}-$ sides, history shows how vain punishment for heresy is. The Church did not burn heretics at the beginning. But what about Huss and Jerome of Prague? They were not heretics but the most Christian men. Their death is to be charged to the pope, not to the Church. The canon law forbids the clergy to bear weapons, but the pope does not care for that, asks for the quick death of the heretics, and tracks them out by the Inquisition. That is not Christian work but Satan's. "O Satan, Satan, Satan, woe to thee with the pope and thy papists." 4

Those are splendid principles. Like benignant stars they shine on us from afar--lonely witnesses for religious freedom in the circle of the great Reformers. But alas! the manysided Luther was not consistent here. He was too hampered by circumstances to be either willing or able to carry through that noble platform. Köstlin acknowledges the contradiction. In Luther's Commentary on Deuteronomy, for in-

$123: 3 \mathrm{r}$. This passage is omitted in later editions.

2 12:283 (2d edition). $\quad 3$ De Wette, ii., 547. 4Op. Var. Arg., v., 221. 
stance, he says that the mad popes and princes, who would compel to faith, assume what no man can do or ought to do, -invade a court which God has reserved for himself. But Luther himself would have the authorities advance against the open proclamation of religious error. ${ }^{x}$ He called on his prince to deprive the Catholic clergy in his land and to let the income go to keep up the Protestant clergy, though provision should be made for the old infirm priests, if they were pious and not against the Gospel. It is also the duty of the Elector to see that the societies support their preachers, if the parochial endowments do not suffice. ${ }^{2}$ The secular authority must see to it that dissension, faction, and tumult do not arise. ${ }^{3}$ This would seem practically to amount to a toleration of the Lutherans and no one else. But Luther by no means at first shared Melanchthon's strict views as to the duty of the state to punish religious error as such, and it is still a question how far he ever really shared them. He says, let everyone believe as he will and preach as he will, and let the spirits rush at each other. It is too bad when such people are murdered. But the authorities should prove the spirits, for that is a bad spirit who reveals himself in breaking down churches and monasteries. If the errorists are actually disorderly then the authorities should interfere. "Luther will have the errorists and fanatics punished," says Hartwig, "only when they endanger public order" (p. 26), which is really the American principle. But Luther was far from separating Church and state as we do. The state must protect us so that we can serve God and thank him 4 ; we have the various classes or estates so that we can learn to kill the flesh, ${ }^{5}$ etc., and "we conclude that every prince is obliged to protect Christians and to see to the externally right worship of God, just as he is under obligation to protect

' Köstlin, Martin Luther: sein Leben und seine Schriften, 5th Aufl., $1: 584$ (1903).

${ }^{2}$ De Wette, iii., I5 (1525).

$23:$ I ff. (Instructions to the Visitors, especially p. 9).

4 I7:193 (I533).

2 I : 240. 


\section{Luther and Toleration}

right preachers and teachers, according to Psalm 82:4, II Kings 9:7, Matthew 10:42, and as, according to Leviticus 24:16, he must ward off blasphemy. Princes are under obligations to plant and to keep in their territories the right teaching." I All public violence and vice and all idolatry and blasphemy must be suppressed by the prince. ${ }^{2}$ The state was not simply a Kulturstaat. It had religious tasks as well. ${ }^{3}$

There was a change in Luther in this matter of the right of the state to interfere in religion. As I have said, the separation of the Church and State and the independent right of the latter were fundamental with him. 4 But its right was chiefly in secular things. When John Frederick of Saxony in 1524 asked Luther to institute Visitors in Thuringia to test preachers and fanatics and to put down incapable pastors with the help of the authorities, Luther refused, because he looked upon it as a stepping over of worldly power into spiritual concerns. ${ }^{s}$ Nor did he take any stock in the synod Hausmann wanted his prince to call that same year to "bring about unity of ceremonies," and for the same reason. It was an invasion of the independent right of the congregations. ${ }^{6}$ Two things broke down Luther's hesitation here: first, the Peasants' War, and second, the unjust seizure of Church goods and lands by private nobles and others, in which seizure the papal knights exceeded the Lutherans. So Luther came to ascribe to the "chief head" both the right and duty of ordering Church matters "after the papal power of the land had lapsed." But this right was not an inherent one in the strict sense, but rather one growing out of historical conditions. The princes "should be asked out of love and for God's sake to take this matter

67:271.

$267: 274$. See also $45: 413$.

3 See Hartwig's correction of Ward (whose book he highly commends, however) in his long review in Theol. Litteraturblatt, 1899, 1 II.

4 53:296 (I525); 55:141-2 (1536).

$s$ Enders, iv., 356-7.

${ }^{6}$ De Wette, ii., 563; vi., 54 (Nov. 17, 1524).

$753: 387$ (1526). 
in hand." At the bottom it was the right of the empire in Diet assembled to arrange these things, saving the forcing of conscience. But as the Diet was not unanimous, it had left ecclesiastical causes to each territory. When pastors therefore wrote Luther of the great need, he urged the Elector to come to the spiritual help of his land. He must see to it that the preachers are supported, and that the youth are educated and piously educated. ${ }^{x}$

Suppose a quiet, loyal, handful of Methodists had lived in Wittenberg in Luther's time. Would he have tolerated them? Would he have advised the Elector to break up their meeting?

He vindicated the rights of the individual [says Harnack] in the first instance for himself; freedom of conscience was for him a personal experience. But for him the free conscience was a conscience inwardly bound, and by individual right he understood the sacred duty of trusting courageously to God, and of rendering to one's neighbor the service of independent and unselfish love. ${ }^{2}$

But still it would be venturesome to conclude too much from these liberating spiritual principles. Probably Mejer-Friedmann are right when they say that all such expressions ("heresy cannot be warded off by force," "God's word is to be used against it") mean only that heresy trials as hitherto known were now a thing of the past; for under the Saxon Visitation Instructions of 1527 (printed I528), drawn up in part by Luther, which were the pattern for so many other state-church ordinances, it was provided that all who would not accept the pure doctrine laid down by the visitors should be threatened as a police measure with banishment; it was that which took the place of a heresy

${ }^{x}$ De Wette, iii., I5 (1526); Erlangen ed., 53:324, 331, 337 (I525), 387 (1526. See Hartwig, 23-25.

'Hist. of Dogma, Eng. tr., vii., 186. 
trial, - otherwise, there was no more tolerance on the part of the Protestant, than on that of the Catholic, side. ${ }^{\mathrm{T}}$

The matter might be traced in this way. First, there were the great ideas of soul liberty which we have quoted from Luther. But the congregation has rights. The procedure here is laid down by Christ (Matthew I8:I6, I7). Heresy becomes a matter for pastoral care and instruction. In case the heretic finally hardens himself then he must be excluded from the Church. This was the course recom-

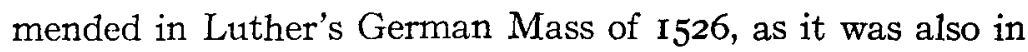
Lambert's Hessian Church Order. Heresy trials belong to the department of Practical Theology, and therewith Luther made a clean sweep of the mediæval method. Not every small thing should be called heresy. "Error does not make heretics," says Luther, "but the defence and obstinacy of error." " Besides heresy is bound to come. There must be offenses (Matthew I8:7). If the time should ever come when there would be no blasphemous doctrine we would have to cease praying, Hallowed be thy name, thy kingdom come. Heresy has a place in God's plans. It shakes up the Church, makes it look around and go farther. It is a plague of the divine anger over the sins of the Church. It keeps the Church watchful. If it had not been for Cerinthus we would not have had John's Gospel. Why should you make the

× Herzog-Hauck, Realencyklopädie f. Prot. Theol. u. Kirche, 3 Aufl, Art. Toleranz, xix., 827 (1907). Mejer-Friedmann give no reference but I suppose they refer to the passage in the preface by Luther (Erl. Ausg., 23:9 [1528]) in which he says that those who set themselves obstinately against these Instructions, who without good ground want to be peculiar (sonderlich), who are wild heads, who out of mere evil cannot endure anything that is equal and common to all, whose hearts and lives are changeable and wayward,- these we must let go from us as the chaff from the threshing floor; for though Your Electoral Grace is not commanded to teach and govern spiritually, yet you are under obligation as a worldly ruler to see to it that no dissension, mobs, and uproars take place among your subjects, just as the emperor Constantine demanded from the bishops at Nicaea, as he would allow no dissension such as Arius had brought about, but held them to united teaching and faith.

- Op. Var. Arg., v., 296. 
heretic a martyr? He is already condemned to all too bitter punishment. Who art thou that invadest God's prerogative? Christ has commanded the tares to grow with the wheat. Then remember that truth is hidden in heresy. "There has never been a heresy which did not also teach something of truth." " "I hold that the reason why heretics are burnt is that those who burn them fear that they cannot overcome them with the Scripture; just as the papists when they see that they cannot stand against the truth strangle the people and with death solve all arguments." 2 So they burn the martyrs at Antwerp, but we cannot do that because it is not Christian. We go to work with Word and Scripture, to vindicate the honor of the divine word. ${ }^{3}$ Luther had three convictions. The first was the certainty that the Word of God alone would bring back heretics, with some exceptions perhaps, to the true faith. The second was that the Holy Spirit, is the interpreter who gives only one interpretation of Scripture, and who impresses that upon the hearts of believers as true. The third was that the interpretation may be found in the creeds, especially in the Apostles', in a brief convenient form.

The next step was a disillusionment in regard to some of these convictions. The heretics had the Word of God and their own interpretation of it, which they would not yield to better instruction. Nor did the Holy Spirit conquer their conception. So Luther's premises vanished. This was followed by the growing danger of the Anabaptists, which

I Walch, iii., 2294 (St. Louis edition, iii., I 553) cf. Erl. Ausg., 23:26I. In this part of the essay I derive much help from W. Köhler (University of Giessen, now of Zürich), Reformation und Ketzerprozess, Tubingen and Leipzig, I901, $8 \mathrm{ff}$.

${ }^{2}$ Walch, xv., 1678 (St. Louis edition, Xv., I4I4).

3 De Wette, ii., 359 ( 1523 ): "Thus far we do the work in quiet ways, but if they shall proceed thus [by force] we might also have recourse to the edict of the Cæsar; not indeed to burn (as they) or bind, or drive any by force (as this is not done by Christians), but to defend the glory of the Word by words and Scriptures [or writings, scripturis], and to correct more widely the monsters [portenta] of the Papists." 
became a real danger in 1525 in the great peasants' uprising. So the question became one of the protection of the subjects from doctrines and from agitators which might lead to subversion of the state or public order. (I speak here from the point of view of those responsible for that order.) The right of interference was guaranteed by various codes of ancient and medirval times which Reformation princes inherited as an essential element of their political consciousness, as modern England inherits the Magna Carta. Besides, the Kaiser, with the consent of the empire, issued his mandate against the Anabaptists in I528-9, which ran in this ominous fashion:

By our imperial fullness of power and right knowledge we ordain, set, make, declare, and will that all Anabaptists, men and women who have come to the age of understanding, shall be executed and deprived of their natural life by fire, sword, and the like, according to opportunity of the persons, and without previous inquisition of the spiritual judges. ${ }^{\mathrm{r}}$

So we have the question of obedience to these laws. How will Luther's liberating principles come out now? Will they survive?

Happily for Luther's consistency, the Anabaptists appeared in a twofold aspect, as heretics, that is, deviating from the Church doctrine as laid down in creeds, and as rebels, that is, as not fulfilling their civil obligations. In the usual accusations three points under this head are mentioned, and they were of course sufficient to condemn them without having recourse to the first head. (I) They will not acknowledge the civil authority as such, as they think the administration of such an office is unchristian. (2) They disdain all oaths, and of course the oath of loyalty. (3) They attack the inviolability of marriage, inasmuch as they allow husband or wife to put away his or her spouse if the latter persists in holding the old church faith. (The rightfulness of these

× Walch, I6: 353 . 
charges, or the policy or justice of proceeding under them, is not now in question.) Of course Luther's course is now clear. If the Anabaptists will not obey the authorities, then the latter should step in with strictness, for the territory of law (Recht) has been invaded. ${ }^{x}$ If it is only a matter of doctrinal opinion, then let Matthew I 8:15-17 form the basis of procedure.

Unfortunately Luther did not stay here. He made another advance. He extended his principle already mentioned-ominously elastic principle! - that the authorities must protect Christianity ("they have the sword and rod in their hands to punish the evil and to protect the pious"). He found that his distinction between heretic and rebel was not sufficient to protect the congregations from the inroads of the Anabaptists. The duty of the authorities to protect the pious was now (about $\mathbf{I}_{52} 8$ and after) expanded to protect religion. Luther came to feel that the acknowledgment of religion belonged to the public weal, the general peace, that it was (as he said) a civic right (Stadtrecht). Das soll man halten oder sich trollen (one should hold that or get out). Heresy thus became a public offense. But how was it a public offense? Luther did not formally class the Anabaptists as blasphemers. "I do not yet hold the fanatics as blasphemers, but rather as Turks or apostate Christians, whom the State has not to punish, especially in body, but if any do not recognize and obey the civil rulers, then "- - that is another question. ${ }^{2}$ But his view that Church and State formed one great Corpus Christianum, distinct in function and task, and yet in some respects mutually dependent and helpful, but utterly rejecting the mediæval conception of the subjection of the State to the Church, led him to the view that this united body has and must have its confession

I Enders, Briefwechsel Luthers, v., I 18 . The reference here is to some Nürnbergers who had denied everything except the existence of God, including the civil power, and who were now in prison (Feb. 4, 1525). See also Köhler, t9.

$=$ Enders, v., II7 (No. 882, Feb. 4, I525). 
of faith-preferably the Apostles' Creed-and that public teaching against that confession is blasphemy.

Where anyone teaches against a public article of faith which is clearly found in Scripture and believed in all the world, such articles as we teach the children in the Credo, for instance, that Christ is not God but a mere man like any other prophet, as the Turks and Anabaptists teach,- these people one shall not suffer, but punish them as public blasphemers. . . Even so shall the authorities punish or not endure those who teach that Christ did not die for our sins, but that each one should do satisfaction himself for them. For that is also a public blasphemy against the Gospel and against the general article where we confess our faith, I believe in the forgiveness of sins, etc. ${ }^{x}$

In the same passage he says that if anyone teaches that no Christian should take public office, should not marry, should have all things in common, etc.,- such should be punished by the authorities. "Heretics by themselves," he says in another place, "heretics may believe what they will, but they must hold their mouth." ${ }_{2}$ With natural and perhaps pardonable self-deception Luther tried to think still that he was consistent with his earlier views, for in the passage just quoted $(39: 250-1)$ he goes on to say that in the above recommendations for the punishment of heretics "no one is compelled to faith. Only the teaching and the blasphemy (Lästern) are forbidden. Let him (the heretic) go where there are no Christians and do the same. For he who would live with citizens should either hold the civil law and not harm or shame it, or get out of the land." But a toleration which would allow one to think but not to speak is not much of an improvement on mediæval liberty. Luther came to feel that no one should be allowed to teach the Gospel but those recognized by the authorities. He goes so far; therefore, to affirm that if such an unauthorized teacher "will not keep silent, let the authorities turn over the rascal to the

\footnotetext{
$\approx$ Erl. ed., 39:250-I (1530).

${ }^{2} 54: 97$ (Aug. 26, 1529). 
right master, to Master Hans (the executioner). That is certainly their right, rather than allowing an uproar or something worse among the people." $x$ "For no preacher however pious and upright should allow himself to preach to a papist or heretic folk belonging to a regular pastor, or secretly teach, without that pastor's knowledge and will." 2 All preachers without regular authorization, even if they preach aright, are simply vagabonds and rascals, and must be referred to Master Hans. ${ }^{3}$ Toleration is thus limited by the consent of the higher powers and by the generally held teachings of the Church. In his letter to Duke Albrecht of Prussia he says that those who reject the articles of faith as they have been hitherto believed by the Church in all ages, or who bring in a new article, such people are not to be suffered, for they burden conscience and mislead and damn souls. ${ }^{4} \mathrm{He}$ discriminates between such commonly received articles and Roman Catholic additions, and thus saves himself from Master Hans. But even under this portentous change of view Luther had no idea at first of the death penalty. In 1528 he thought that banishment was sufficient, and that death should be reserved for tumultuous heretics "who will not be quiet until they see Germany soaked with blood."s Some years later he gave his consent-easy is the descent into Avernus-for even the death penalty, and it was in this wise. Melanchthon had written a careful paper on the treatment of the Anabaptists for the benefit of his elector (in $\mathrm{I530}$ ), in which he recommends a graduated scale of punishments. Those who are disobedient to authority, are communists, refuse to take the oath, etc., can be put to death. Even for those who "hold that our (Lutheran) baptism and preachers are not Christian and that our Church is not a Cinristian one," these also may be punished by the "punishment of the codex" (death). For those, however, who have fallen into error through simplicity, who are not

\footnotetext{
1 39:255 (1530).

239:254.

$343: 313(1532)$.

454:288-9 (probably April, 1532). 5 Enders, vi., 289 (June 14, I 528).
} 
tumultuous, these may be banished or punished with other milder punishments in order to bring them to betterment, and according to circumstances these punishments may be made sharper or milder. To this deliberate program of persecution Luther set his placet in these words: "Though it looks cruel to punish them (the Anabaptists) with the sword, yet it is more cruel that they condemned the ministry of the word and teach no certain doctrine, and suppress the right doctrine, and thus destroy the kingdoms of the world." $x$

By clear implication this encourages death, if necessary, for religious error.

In a decision signed by Luther, Bugenhagen, Cruciger, and Melanchthon, in answer to a request from Philip of Hesse, who as a broad-minded layman was not as much inclined to persecute as the theologians, they held (I536) that it was "very easy to judge where the Anabaptist articles have to do with worldly rule, for there is no doubt that in such a case the obstinate should be punished as turbulent, and if circumstance favor even with the sword. Where the articles have to do with spiritual things only and are false, we conclude that in this case the obstinate may also be killed." In this celebrated paper Luther flatly places all serious doctrinal error and erroneous worship on the same platform as perjury and blasphemy, and-referring to Leviticus 24:II-I6-calls for its possible punishment by the sword. He includes even the denial of infant baptism, as such denial would lead to public heathenism! Those also who on the ground of the impurity of the Church separate from her and meet in their own assemblies, shall be punished by death if necessary. But careful discrimination should be made, and the simple brought back if possible. Here Luther forsakes utterly his old standpoint, and goes out with fire and sword against religious error. The letter of 1536 might almost be called the Lutheran apotheosis of persecution. ${ }^{2}$

I Corpus Ref., iv., 740 (I530).

${ }^{2}$ See this paper in Walch, $20: 2 \mathrm{I} 82 \mathrm{ff}$., and in Zeits. f. Hist. Theol., $1858,560-65$. 
That was the Great Surrender! The Church is now not simply the fellowship of believers but a legal institution, protected by the state, hedged about with the creeds; the mother of souls, but also the protectress of pure doctrine. Hence after 1533 ministers had to be first obligated to the Apostles' Creed, then to the Nicene, the Athanasian, and the Augsburg. This reacted to exalt the teachers of the Word as the defenders of the faith in Luther's eyes. The pastor became exalted over the congregation. In $153^{\circ}$ Luther writes to Justus Menius that in his book against the Anabaptists he should more strongly bring home to them that they have no regularly called preachers. "For that is a plain sign that they are the servants of the devil." ${ }_{I}$ In the Church itself the only punishment for heresy is still only exclusion, according to Matthew I8:I5. But that meant more then than it does now. In the Church ordinances of the time we read of decrees forbidding the ringing of the church bells and honorable burial of the "heretics," and then finally of open anathema. But Luther's progress was not only intensive as to punishment but also extensive as to victims. It was now not only the poor Baptists, but also even $Z$ wingli "and other sets and sects." ${ }_{2}$

The inner connection between faith and tradition [says $\mathrm{W}$ Köhler] in which faith was the ruling prius, and in the tradition found an expression of itself, was separated, so that the traditional confession took the first place and demanded not so much personal faith as legal acknowledgment. And what before the divine Word had to do, that is conquer the heretics by virtue of itself, had to be done now by the Creed, but no longer by the

$x$ De Wette, iii., 570.

2 See Köhler, 24-29. Luther subscribed the paper which made the authorities the protector of the first table of the law as well as the second (Corp. Ref., iii., 225). Kawerau explains (Theol. Lit.-Zeit., I902, 107-9) this latter attitude of Luther by the consideration that the Anabaptists were looked upon as underminers of all state order. But Luther's scythe cut a much wider swathe. $\mathrm{He}$ came to believe in the forcible suppression of heresy as such. 
Creed itself, but supported both by the secular and by the spiritual authorities. Not simply the Confession did this but the churchly interpreted confession,--and so came the increased emphasis oxt the ministerial office. In this way the strain upon the one interpretation of Scripture was released, so that the Creed, as the Church conceived it, became the norm of interpretation. Still it was of no advantage to the Baptists that in their Schlatten Articles (1527) they built upon the Apostles' Creed!r

Nevertheless the use of force was a "strange work" with Luther. In his letter to Beier in Zwickau in 1533 he says:

Those who despise all piety, do not come to meeting, we are accustomed at first to frighten by the authority and name of our illustrious prince, and to threaten with $e$ ile and punishment, as against blasphemers. Then, if they do not have a care, we give commandment to the ministers (parochis) to instruct them for a whole month or more, to teach them, to reprove them; nevertheless, if they are hardened, they are to be excluded from society (coetu), and to be avoided as heathen. The passage is clear concerning excommunication in Scripture. Nevertheless if they are not restored by common remedies, you can write again on this matter. ${ }^{2}$

I am very slow [he says again] in a judgment of blood, even where there is abundant cause. For in this matter the consequences of the example terrify me, which we see among the papists and before Christ among the Jews; where, when the law provided that false prophets and heretics ought to be slain, it happened in the process of time that only the holiest prophets and innocents were killed, by the authority of that same law, by which impious magistrates made false prophets and heretics of whomsoever they wished. I fear the same thing may happen among us if once it could be proved by a single example [in the Bible] that seducers should be slain, when we see that hitherto among the papists by the abuse of this law innocent blood has been poured out instead of the guilty. Wherefore it cannot at all be admitted that false teachers should be slain; it is sufficient

' Lib. cit., 32-33.

3 Enders, ix., 365 (No. 2135). 
that they be banished. If posterity desires to abuse this punishment, they will nevertheless sin more mildly and hurt only themselves. ${ }^{\text {I }}$ Yes, dear God, how soon has it happened that one errs and falls into the snare of the devil. One should defend and oppose with Scripture and God's Word, with fire one can do but little. ${ }^{2}$

It is to the credit of the Lutheran theologians that in the carrying out of the imperial mandate against the Anabaptists they urged mildness and instruction, and Hermelink does well to refer to contemporary feeling on penal matters, in which the theory of warning or deterring was in fearful vogue. It was a time when poachers lost their eyes, counterfeiters their lives, and which demanded a penalty hardly less for the falsification of the common faith. ${ }^{3}$

These factors must also be remembered as historically explaining Luther's course. (I) The tremendous influence of the Old Testament. Though at times Luther got a glimpse of the preparatory character of the Old Testament, it is undeniable that its influence was weighty in this and other matters. (2) His inability to conceive two opposing "preachings" or congregations in the same town without danger to the social order. Anabaptist tragedies perhaps dis rupted in this respect the serene faith of the Reformer. They made it impossible for him to think of the quiet coexistence of opposing confessions. "Worldly authority," he says, "should not permit disunion or division among the people brought about by contrary preachers, from which state of things uproar and riots might be feared, but in one place only one kind of preaching should be permitted." $4 \mathrm{He}$ carried this so far as to say that even for his own faith its preachers must be silent where they are not wished. If this cannot be done, "then let the authorities hear the cause

I Enders, vi., 299 (July I4, I528).

2 Erl. ed., 26:256 (I528).

3 Der Toleranggedanke im Reformationszeitalter, Leipzig, 1908, 53 (Schr. d. Ver. f. Ref. Gesch., 96).

453:368; De Wette, iii., 89 (Feb. 9, r526). 
(i. e., weigh both sides), and whichever side does not agree with the Scripture must be commanded to be silent. For it is not good that a parish should allow contrary preaching among the people; for from that spring riots, dissatisfaction, hatred, envy, and even in worldly matters." I (3) His belief in a ministry that was both educated and authorized. To his mind a Winkelprediger, an unlicensed preacher, was what a hedge-lawyer or a quack doctor is to ours, both contemptible in himself and a menace to public health and decency. (4) The practice in the German states in the closing fifteenth century for the princes to look often after ecclesiastical affairs. And (5) the dread lest what had been gained for the Gospel would be lost in the confusion of conflicting sects and factions, and the papal power come in again as the only hope of unity and peace.

But the question remains: What if there had been no Peasants' War? What if there had been no Jan of Leyden? no Thomas Münzer? What if all the Anabaptists had been the quiet inoffensive folk some of them were? Would this fateful evolution have taken place in Luther? Would not his earlier principles have asserted themselves with living fruitfulness all the way through? So we trust and hope. For the earlier Luther was the greater and the nobler. Or, I should say, the Luther of the joyful trust in the Gospel was greater than the Luther who turned to the magistrate as the hammer of heretics, for the sentiments of that joyful trust are not confined to his earlier writings. There were rather two Luthers in one. For to the last he held that "no one should be compelled to faith," that in the Church itself only the method of Matthew 18:15 holds, and that when the state interferes to punish heretics it does so not on account of the Church, nor on account of the soul of the heretic or of others, but on account of the good of the state itself, as the protectress of her public life. The state is not the executive of the Church, nor is she to be prompted by the Church,--she

s 39:252 (1530). 
acts in her own right. In this teaching Luther parted finally from the mediæval world-view, and ushered in the modern era.

Note. In a brief historical note in The Presbyterian and Reformed Review, January, 1897, 99-102, the late Rev. Dr. Dunlop Moore, of Pittsburgh, calls attention to the intolerant word of Luther concerning the Jews in his Von den Juden und ihren Lügen (1542, Walch edition, xx., $2476 \mathrm{ff}$.). It is fair to say, however, that Luther had understood that the Jews were trying to entice Christians to come over to them, that they were indulging in blasphemies and wild hate (including the curse-prayer in their synagogues), and that they were exploiting the Christians by usury. They should be expelled from the country, but this should be done by the authorities, and individual Christians should not harm them. In his Rector's address for 1907, Professor Loofs (Luthers Stellung zum Mittelalter und zur Neuzeit, Halle, 1907, 17-19) acknowledges that Luther did not keep true to his early principles in the matter of toleration, but claims that we cannot for that reason immediately class him, as Tröltsch does, with mediæval men: "Did we not have the compulsory baptism law till I874? Is not blasphemy still punishable among us? And have we not to-day a Christianly-colored Autoritätskultur with its obligatory instruction in religion? Our time is not as much opposed to the thoughts of Luther as Tröltsch supposes." Walther of Rostock, in his able and on the whole fajr defense of Luther (Für Luther wider Rom. Handbuch der Apologetik Luthers und der Reformation den römischen Anklagen gegenüber, Halle, 1906, pp. xv, 759), gives a long discussion of Luther's attitude to toleration (pp. 245-417). Walther admits (p. 315) that Luther conceded that heretics who were not a menace to the public peace might be put to death. Professor H. Boehmer, of Bonn, now of Marburg, in his most admirable study of Luther, Luther im Lichte der neueren Forschung, Leipzig, 1906, second edition, 1909, while acknowledging that Luther fully changed his standpoint, thinks (p. I67, second edition) that his sharp utterances cannot be taken earnestly. I cannot agree with Boehmer here. While there were times when Luther spoke half-jokingly, or in an overwrought condition, this was not one of them. In the sermon of February 7 , I546, referred to by Boehmer, he seems to be speaking only of the 
attitude of preachers (not the authorities) to the driving out of heretics, Jews, etc. Hunzinger (Die Theologie der Gegenwart, iii., 3, 48,1909 ) goes further than Boehmer in the same direction, as does Otto Ritschl, Dogmengeschichte des Protestantismus, i., 1908; but the documents quoted above yield rather stubborn results for this idealistic view. W. Köhler (see above) is more objective. "Certainly," he says, "Luther would have approved the execution of Servetus. Even according to him, heresy as heresy deserved death" (Theol. Literaturzeitung, 1906, 2 I I). The student can refer also to another Protestant historian, Wappler, Inquisition und Ketzerprozesse in Zwickau zur Reformationszeit dargestellt im Zusammenhang mit der Entwicklung der Ansichten Luthers und Melanchthons uber Glaubens- und Gewissensfreiheit, Leipzig, 1908, and his Die Stellung Kursachsens und des Landgrafen Philipp von Hessen zur Täuferbewegung, Munster i. W., 1910,both important. On the Catholic side see the great books of Denifle and (better) Grisar on Luther (see index under words Gewissensfreiheit, Intoleranz, Toleranz, etc.), and especially the thorough investigation of Paulus, Protestantismus und Toleranz im I6. Jahrhundert, Freiburg i. Br., I9I I, 374 pp. (pages I-6I are devoted to Luther). See also (Protestant) Köstlin-Kawerau, Luther, 5. Aufl., 1903, index under Ketzerverfolgang, Toleranz; Köstlin, Luthers Theologie, 2. Aufl., I901, i, 342-4, ij, 322-3; Walther in Theol. Lit.-Blatt, I901, 595-7; Sohm, Kirchenrecht, 1892, pp. 542 ff.; Friedberg, Kirchenrecht, 5. Aufl., 1903, see index under Toleranz; Völker, Karl, Toleranz und Intoleranz im Zeitalter der Reformation, Leipzig, I9I2. This last is perhaps the best discussion of the subject we have. Its conclusions confirm those of this paper. Paul Drews, Entsprach das Staatskirchentum dem Ideale Luthers? Tübingen, 1908 (answered in the negative; on pp. 99-102 gives admirable statement of attitude to toleration). I have also read Poincenot, Les Idées de Luther sur la Répression de l'Hérésie, Montbéliard, I9oI, and Ruffini's History of Liberty, London and New York, 1912, first published in Italian in rgor (see Theol. Jahrsber., 1901, 62), both of whom arrive at the same results as those above. There is a fresh and very suggestive treatment of toleration (including Luther's attitude, pp. 720723) by George Lincoln Burr, Anent the Middle Ages (American Historical Review, vol. 18, July 1913, 710-726). 